\title{
Monetary Policy Actions, Macroeconomic Data Releases, and Inflation Expectations
}

\author{
Kevin L. Kliesen and Frank A. Schmid
}

D

o surprises in macroeconomic data releases and monetary policy actions of the Federal Reserve lead economic agents to update their beliefs about the rate of inflation? If so, which macroeconomic data releases matter for inflation expectations? Does Federal Reserve communication (for example, speeches and testimonies by Fed officials) affect the uncertainty surrounding the rate of inflation that economic agents expect for the following 10 years? These are some of the questions we are trying to answer in this paper.

We gauge inflation expectations by two different concepts of inflation compensation, both of which are derived from the market valuation of the expected cash flows of nominal Treasury securities versus inflation-indexed Treasury securities (TIIS). We look at 35 macroeconomic data series (for example, the monthly change in nonfarm payroll employment) and determine whether daily changes in inflation compensation are associated with the surprise component in these series. We define the surprise component as the difference between the expected and the actually released value of the series, normalized by the degree of uncertainty surrounding these expectations. The time period of our analysis is January 31, 1997, to June 30, 2003, for one concept of inflation compensation and January 4, 1999, to June 30, 2003, for the other. For the 35 macroeconomic data series, we find the following: for 17 , the surprise component in the announcement has no bearing on inflation expectations; for 5 , the surprise component has an effect on one measure of inflation expectations, but not on the other; for 13 , the surprise component in the release consistently affects inflation expectations, independent of the employed concept of inflation compensation. Further, we show that monetary policy actions that are tighter or easier than expected by the federal funds futures market have a statistically significant effect on the expected rate of inflation, independent of the employed concept of inflation compensation. Finally, we provide evidence that Federal Reserve communication and surprises in monetary policy actions bear on the uncertainty surrounding the expected rate of inflation. For one concept of inflation expectations, we find that Federal Reserve communication reduces uncertainty about the future rate of inflation, while surprises in monetary policy actions increase this uncertainty. For the other concept of inflation compensation, we find no such effects.

\section{RELATED LITERATURE}

The effect of macroeconomic announcements on inflation compensation embedded in the market valuation of expected cash flows of nominal Treasury securities versus TIIS has been investigated before.

The studies most closely related to our work are Sack (2000) and Gürkaynak, Sack, and Swanson (2003). Using daily data, Sack (2000) analyzes how surprises in the releases of six monthly macroeconomic data series affect the inflation compensation embedded in Treasury securities for the period 1997-99. These macroeconomic data series are the consumer price index (CPI), the CPI excluding food and energy (core $\mathrm{CPI}$ ), the producer price index for finished goods (PPI), nonfarm payroll employment, retail sales, and the NAPM index. ${ }^{1}$ Sack matches the on-the-run 10-year TIIS with a portfolio of nominal Treasury STRIPS (Separate Trading of Interest and Principal Securities) that replicates the pattern of expected payments of the TIIS. ${ }^{2}$ The author finds a

\footnotetext{
1 The National Association for Purchasing Managers' (NAPM) index is now simply the Purchasing Managers Index; it is released by the Institute for Supply Management.

2 The Treasury STRIPS program, which was introduced in January 1985 , "lets investors hold and trade the individual interest and principal components of eligible Treasury notes and bonds as separate securities" (www.publicdebt.treas.gov/of/ofstrips.htm).
} 
statistically significant response of inflation expectations to surprises in the CPI, the core CPI, retail sales, and the NAPM index.

Gürkaynak, Sack, and Swanson (2003) analyze the response of inflation compensation embedded in one-year nominal versus inflation-adjusted forward interest rates to surprises in macroeconomic data releases and Federal Reserve monetary policy actions - that is, changes to the Federal Open Market Committee's (FOMC) federal funds target rate. The forward rates are derived from the yields of 10-year Treasury securities - the TIIS and nominal securities. The pair of one-year forward rates that the authors study is the one for the 12-month time window between the maturity dates of the on-the-run 10year TIIS and the (off-the-run) TIIS issued 12 months earlier. Prior to July 2002, and starting in 1997, 10year TIIS were issued only once per year, in January. This implies that the authors analyze changes to the inflation rate that is expected to prevail during a 12-month time window that starts, on average, 8.5 years from the time of the data release. The sample period runs from January 1997 through July 2002 and covers 39 macroeconomic data series. The authors show that the rate of inflation expected to prevail in about nine years' time correlates positively with surprises in consumer confidence, consumer credit, the employment cost index (ECI), gross domestic product (GDP, advance), new home sales, and retail sales and negatively with surprises in the federal funds target rate. The authors conclude (on p. 2) that their "empirical findings suggest that private agents adjust their expectations of the longrun inflation rate in response to macroeconomic and monetary policy surprises."

Like Gürkaynak, Sack, and Swanson (2003), we analyze Treasury securities with a 10-year maturity. Unlike those authors, we study the average inflation rate expected for the next 10 years rather than the value expected for a 12-month window late in this time period. In other words, we make no statement about whether (and, if so, the degree to which) surprises in monetary policy actions and macroeconomic data releases affect the rate of inflation that economic agents expect to prevail in 8 to 9 years.

Another study related to ours is by Kohn and Sack (2003), who study the effect of Federal Reserve communication on financial variables but make no attempt to gauge the influence that Chairman Greenspan's speeches and testimonies have on the level of Treasury yields. Rather, the authors measure the effect of Fed communication on Treasury yield volatility. These authors investigate the effect that Federal Reserve communication has on various financial variables by using daily observations for the period January 3, 1989, through April 7, 2003. Federal Reserve communication comprises statements released by the FOMC and, since June 1996, congressional testimonies and speeches delivered by Chairman Greenspan. Among the financial variables Kohn and Sack analyze are the yields (to maturity) of the 2-year and 10-year Treasury notes. These authors find that statements of the FOMC and testimonies of Chairman Greenspan have a statistically significant impact on the variance of 2-year and 10-year Treasury note yields; no such effect was found for Chairman Greenspan's speeches. We follow Kohn and Sack (2003) and study the effect of Federal Reserve communication on the (conditional) volatility of inflation compensation - that is, on the uncertainty that surrounds the future rate of inflation.

\section{MEASURES OF INFLATION COMPENSATION}

In 1997, the U.S. Treasury introduced TIIS. These securities are issued alongside traditional (nominal) Treasury securities. Both types of securities are endowed with a fixed coupon yield-that is, the coupon payment per annum as a percent of the principal. Unlike the principal of the nominal Treasury, which is fixed for the lifetime of the security, the principal of the TIIS is adjusted daily to past changes in the rate of inflation, as measured by the (not seasonally adjusted) CPI for all urban consumers. The coupon payments of TIIS are made off of the inflationadjusted principal. If the rate of inflation turns negative, the principal is adjusted downward, possibly dropping below the par amount at issue. At maturity, TIIS are redeemed at their inflation-adjusted principal or par value at issue, whichever is greater.

It has become common practice to gauge inflation expectations - that is, expectations about the future, average rate of change in the CPI-from the inflation rate at which the market prices of comparable TIIS and nominal Treasury securities break even. To illustrate the theoretical motivation of this concept, consider, as an example, two default-free securities with annual coupon payments, identical coupon yield, an original principal of $\$ 1$, and a time to maturity of one year. One is a nominal Treasury security and the other is a TIIS. For the two securities to deliver the same return to an investor who is indifferent to inflation risk (but not to inflation, of 
course), the following equation must hold:

$$
\frac{1+c}{p^{n}}=\frac{(1+\pi) \cdot(1+c)}{p^{i}},
$$

where $c$ is the coupon yield, $\pi$ is the expected rate of inflation, and $p^{n}$ and $p^{i}$ are the prices of the nominal security and the TIIS, respectively. Solving equation

(1) for the expected rate of inflation delivers

$$
\hat{\pi}=\frac{\frac{1+c}{p^{n}}}{\frac{1+c}{p^{i}}}-1 \equiv \frac{y^{n}-y^{i}}{1+y^{i}} \approx y^{n}-y^{i},
$$

where $y^{n}$ and $y^{i}$ are the yields to maturity of the nominal security and the TIIS, respectively. Equation (2) states that the break-even inflation rate, $\hat{\pi}$-that is, the expected rate of inflation at which the two securities trade at the same price-can be approximated by the difference in the yields to maturity between a nominal and an inflation-indexed security. For securities of more than one year to maturity, matters are more complex but the same principle applies.

Although the break-even rate of inflation makes up the bulk of the inflation compensation embedded in the market valuation of the expected cash flows of nominal securities versus TIIS, there is also compensation for inflation risk. Hence, the embedded inflation compensation exceeds the expected rate of inflation. Further, for positive rates of inflation, the payment stream on TIIS is back-loaded compared with the cash flow of nominal Treasury securities. This is because the TIIS principal and, hence, the coupon payments grow with the price level. Because the payment stream of TIIS is back-loaded, their duration with respect to the real (that is, inflationadjusted) term structure of interest rates is longer than the duration of nominal Treasury securities. In other words, the two types of securities do not have the same price sensitivity to real interest rates. Hence, the real-interest-rate risk (and thus the amount of compensation for this type of risk) might differ between the two securities; this may distort the measured inflation compensation. For technical details on the differences between the two securities, see Emmons (2000) and Sack (2000).

A simple and readily available concept of inflation compensation is the difference in yields to maturity between the on-the-run nominal Treasury security and the on-the-run TIIS of the same original time to maturity. This concept of gauging inflation expectations has four major disadvantages. First, and most importantly, the market for nominal Treasury securities is more liquid than the market for TIIS, which may cause the yield spread to understate the expected rate of inflation by a liquidity premium (Sack, 2000). Second, nominal Treasury securities and TIIS might not have the same duration with respect to real interest rates, which might cause the compensation for real-interest-rate risk in the yields of the two securities to differ. Third, the two types of securities might not be issued at the same dates and with the same frequency. Hence, the two on-the-run securities might not have the same remaining time to maturity. For instance, whereas nominal 10-year Treasuries are issued several times per year, the corresponding inflation-indexed securities are issued only once (1997-2001) or twice (2002) per year. Fourth, the remaining time to maturity of on-the-run securities varies because new securities are not issued every trading day.

To avoid some of the drawbacks that come with the simple difference in yields between the on-therun nominal and inflation-indexed securities, we derive inflation compensation from a smoothed zero-coupon yield curve estimated from off-the-run nominal Treasury coupon securities. We use two different measures for the inflation-indexed yield. The first measure uses the on-the-run TIIS-the OTR measure. The other measure uses a smoothed zerocoupon yield curve estimated from TIIS, which allows us to compare the nominal and inflation-indexed yields at constant maturity - the CM measure.

\section{THE DATA}

Our analysis covers the period from January 31 , 1997, to June 30, 2003, for the OTR measure, and from January 5, 1999, to June 30, 2003, for the CM measure. Each period begins on the starting date of the respective daily data series, provided by the Board of Governors of the Federal Reserve System. Both series contain missing values (OTR: 53; CM: 16) - that is, have trading days for which no OTR or $\mathrm{CM}$ observation is on record. The macroeconomic data releases are from Money Market Services. The dataset comprises median polled forecast values for 38 macroeconomic data series, along with the sample standard deviations of these forecast values. The Money Market Services survey is conducted every Friday morning among senior economists and bond traders with major commercial banks, brokerage houses, and some consulting firms mostly in the greater New York, Chicago, and San Francisco 
areas. Among these 38 series in the survey, there are three items-CPI, PPI, and retail sales-for which there also exists a "core" concept. Whereas the comprehensive items of the CPI and the PPI include food and energy items, the respective core measures do not. For retail sales, the narrowly defined concept excludes automotive sales. In the regression analysis, we exclude the three "core" concepts, which leaves us with 35 macroeconomic variables. ${ }^{3}$ Data that were released on days when the markets were closed were moved to the next trading day - the day on which this information could be priced in the marketplace.

We try to relate daily changes in inflation compensation to the surprise component in macroeconomic data releases. We define the surprise component as the difference between the actual and the median forecast values, normalized by the sample standard deviation of the individual forecasts. ${ }^{4}$ We also control for Federal Reserve communication and actions. Our concept of Federal Reserve communication comprises (i) Chairman Greenspan's semi-annual testimony to Congress (formerly known as Humphrey-Hawkins Testimony) and (ii) speeches and other testimonies of Chairman Greenspan. Consistent with the macroeconomic data releases, we moved Federal Reserve communication to the next trading day if this communication occurred after-hours (that is, after the data input for the inflation compensation measures were recorded) or on days on which there was no trading. Finally, we control for the surprise component in changes (or the absence thereof) of the federal funds target rate, which we measure as suggested by Kuttner (2001) and discussed by Watson (2002). For each scheduled and unscheduled FOMC meeting, we scaled up by $30 /(k+1)$ the change of the price of the federal funds futures contract for the current month on the day of the FOMC meeting, $t$, where $t+k$ denotes the last calendar day of the month. ${ }^{5}$ Note that this variable is not on the same scale as

\footnotetext{
3 As will be discussed, our exclusion of the "core" variables did not materially change our empirical results.

4 Fleming and Remolona (1997, 1999) calculate the surprise component by normalizing the difference between the actual and the forecast values by the mean absolute difference observed for the respective variable during the sample period. Balduzzi, Elton, and Green (2001) normalize the difference between the actual and the forecast values by the standard deviation of this difference during the sample period. Gürkaynak, Sack, and Swanson (2002) do not normalize their variables.

5 Following Gürkaynak, Sack, and Swanson (2003), we use the (unscaled) change in the price of the federal funds futures contract due to expire in the following month if the FOMC meeting took place within the last seven calendar days of the month.
}

the surprise component in the macroeconomic data releases. In a sensitivity analysis, we use an alternative measure of the surprise component in monetary policy actions. This alternative measure, devised by Poole and Rasche (2000), rests on price changes of federal funds futures contracts also. ${ }^{6}$

Table 1 shows the frequency with which releases of the 38 macroeconomic data series match recorded OTR and CM inflation compensation during the two respective sample periods. The numbers of data releases during the sample period are in parentheses, and the differences in the two numbers are due to missing values. We also report matches for scheduled and unscheduled FOMC meetings - the federal funds target variable, the surprise component of which was calculated as outlined above-and the two Federal Reserve communication variables defined above-(i) semi-annual testimony to Congress and (ii) Greenspan speeches, testimonies other than semi-annual testimony to Congress. The only weekly series in the dataset, initial jobless claims, has the highest frequency. The next-to-highest frequency is observed for testimonies other than semi-annual testimony to Congress, followed by monthly data releases, FOMC actions (federal funds target), quarterly data releases, and the Chairman's semi-annual testimonies to Congress. An exception is nonfarm productivity, which entered the Money Market Services dataset during the sample period; the first surveyed number refers to the first quarter of 1999.

Table 2, center column, offers a frequency distribution for the coincidence of surprises in macroeconomic data releases (Money Market Services survey) and monetary policy actions. For instance, for the OTR measure of inflation expectations, 453 of the 1,555 trading days analyzed had no surprises in data releases or monetary actions, possibly because no data were released or no action taken; 615 trading days (40 percent) had more than one surprise; and 270 (17 percent) had more than two surprises. Table 2 , right column, offers a frequency distribution with Federal Reserve communication included.

\section{EMPIRICAL FINDINGS}

Our empirical approach rests on the following regression equation:

\footnotetext{
6 For a discussion of measures of market expectations concerning monetary policy actions, see Gürkaynak, Sack, and Swanson (2002).
} 


\section{Table 1}

\section{Number of Data Releases That Match Inflation Compensation Observations}

Data series (FOMC communication and actions)

OTR measure

CM measure

Auto sales

75 (78)

$51(54)$

Business inventories

$76(78)$

54 (54)

Capacity utilization

$77(78)$

$54(54)$

Civilian unemployment rate

75 (78)

$54(54)$

Construction spending

75 (78)

$51(54)$

Consumer confidence

$76(78)$

54 (54)

Consumer credit

Consumer price index (CPI-U)

77 (78)

$54(54)$

75 (78)

$54(54)$

$\mathrm{CPI}$ excluding food and energy

75 (78)

$54(54)$

Durable goods orders

75 (78)

$54(54)$

Employment cost index (Q)

25 (26)

$18(18)$

Existing home sales

$76(78)$

$54(54)$

Factory orders

Federal funds target: unscheduled FOMC meetings*

$75(78)$

$53(54)$

Federal funds target: scheduled FOMC meetings*

4 (4)

2 (3)

GDP price index (advance) $(\mathrm{Q})$

$51(52)$

$36(36)$

GDP price index (final) (Q)

25 (26)

18 (18)

25 (26)

18 (18)

GDP price index (preliminary) (Q)

25 (26)

18 (18)

$76(78)$

$54(54)$

Greenspan speeches, testimonies other than semi-annual testimony to Congress*

$130(135)$

$89(90)$

Hourly earnings

$75(78)$

$54(54)$

Housing starts

$76(78)$

$53(54)$

Industrial production

77 (78)

54 (54)

Initial jobless claims (W)

$323(334)$

224 (234)

Leading indicators

75 (78)

53 (54)

Purchasing Managers' Index

75 (78)

51 (54)

New home sales

Nonfarm payrolls

75 (78)

53 (54)

75 (78)

54 (54)

Nonfarm productivity (preliminary)

$16(17)$

17 (17)

Nonfarm Productivity (revised)

17 (17)

75 (78)

17 (17)

Personal consumption expenditures

$75(78)$

53 (54)

Personal income

Producer price index (PPI)

PPI excluding food and energy

$76(78)$

$53(54)$

$76(78)$

54 (54)

25 (26)

54 (54)

Real GDP (advance) (Q)

25 (26)

18 (18)

Real GDP (final) (Q)

25 (26)

18 (18)

Real GDP (preliminary) (Q)

$76(78)$

18 (18)

Retail sales

$76(78)$

54 (54)

Retail sales excluding autos

12 (13)

54 (54)

Semi-annual testimony to Congress*

$74(78)$

8 (9)

Treasury budget (surplus)

75 (78)

$53(54)$

51 (54)

NOTE: Monthly series if not indicated otherwise (Q, quarterly; W, weekly). Numbers in parentheses indicate total number of observation, not all of which are used because of missing observations for the measures of inflation compensation.

*Variables not included in the dataset of macroeconomic data releases. 


\section{Table 2}

\section{Frequency Distribution of Coincidence in Surprises}

\begin{tabular}{|c|c|c|c|c|}
\hline \multirow{3}{*}{$\begin{array}{l}\text { Number of surprises } \\
\text { per trading day }\end{array}$} & \multicolumn{4}{|c|}{ Number of observations } \\
\hline & \multicolumn{2}{|c|}{$\begin{array}{l}\text { MMS survey and } \\
\text { federal funds target }\end{array}$} & \multicolumn{2}{|c|}{$\begin{array}{l}\text { MMS survey, } \\
\text { federal funds target, and } \\
\text { Federal Reserve communication }\end{array}$} \\
\hline & OTR & $\mathrm{CM}$ & OTR & $\mathrm{CM}$ \\
\hline 0 & 453 & 323 & 415 & 298 \\
\hline 1 & 487 & 335 & 488 & 329 \\
\hline 2 & 345 & 249 & 355 & 265 \\
\hline 3 & 147 & 112 & 159 & 113 \\
\hline 4 & 86 & 68 & 96 & 79 \\
\hline 5 & 21 & 10 & 25 & 13 \\
\hline 6 & 10 & 9 & 10 & 8 \\
\hline 7 & 3 & 2 & 3 & 3 \\
\hline 8 & 1 & 1 & 2 & 1 \\
\hline 9 & 2 & 1 & 2 & 1 \\
\hline Total & 1,555 & 1,110 & 1,555 & 1,110 \\
\hline
\end{tabular}

(3) $\hat{\pi}_{t}-\hat{\pi}_{t-1}=\alpha+\beta \cdot D+\sum_{k=1}^{35} \delta_{k} \cdot x_{t}^{k}+\gamma \cdot f f_{t}+\varepsilon_{t}$,

where $\hat{\pi}_{t}-\hat{\pi}_{t-1}$ is change in the inflation compensation from trading day $t-1$ to trading day $t, D$ is an indicator variable that is equal to 1 if all explanatory variables are equal to 0 (and is equal to 0 otherwise), $x_{t}^{k}$ is the surprise component in the macroeconomic data release, $f f_{t}$ is the surprise component in the Federal Reserve action (the federal funds target variable), and $\varepsilon_{t}$ is an identically and independently distributed error term with mean 0 and finite variance $\sigma^{2}{ }^{7}$ The dependent variable is, alternately, the OTR and the CM measures of inflation compensation. ${ }^{8}$

We expect signs on the surprises in the macroeconomic data releases to be consistent with the conventional macroeconomic theory as taught in the classroom. Bernanke (2003) presents a brief summary of this theory using the expectations -

7 The intercept indicator variable, $D$, eliminates the influence on the observed mean of the dependent variable of those observations for which none of the explanatory variables contains information pertinent to the measured inflation compensation.

8

Using kernel estimation, we verified that the dependent variables are close to normally distributed. Yet, there is mild (and statistically significant) skewness (OTR: 0.402; CM: 0.409) and excess kurtosis (OTR: 1.673; CM: 1.114) augmented Phillips curve. In this model, inflation depends on inflation expectations, the output gap, and supply shocks. The most important determinant of inflation is the expectation component. Anything that causes people to expect more inflation is likely to lead to behavior that causes higher inflation. Forecasting models and studies using surveys of inflation expectations show that the most important variable in predicting future inflation is past inflation. ${ }^{9}$ Therefore, we expect surprise increases in price indices (such as the CPI or PPI) to lead to higher inflation expectations.

We assume that real variables affect inflation indirectly through the output gap, that potential output is relatively stable (as measured by the Congressional Budget Office, $\mathrm{CBO}$ ), and that most news about real activity is news about aggregate demand. Therefore a surprise increase in any subset of real economic activity may lead to expectations of higher inflation. The Phillips curve model also performs better if we account for supply shocks. A surprise in real activity may be associated with a supply shock rather than an aggregate demand shock. The real variable included in this study that

\footnotetext{
9 See Stock and Watson (1999) for evidence about the role of past
} inflation and real variables in predicting inflation. 
is explicitly thought to measure changes in aggregate supply is labor productivity.

The expected sign of the federal funds target variable is negative. Remember that this variable measures the surprise in the choice of the federal funds target rate at scheduled and unscheduled FOMC meetings. We predict economic agents to revise down (up) their expected rate of inflation in response to FOMC actions that are indicative of monetary policy tighter (easier) than expected.

Tables 3 and 4 show the regression results for the OTR and CM measures, respectively. ${ }^{10}$ The regression coefficients of the federal funds target variable have the expected sign and are statistically significant. A surprise in the expected federal funds target rate of 10 basis points reduces the expected rate of inflation by 2.2 basis points (OTR measure) and 1 basis point (CM measure), respectively. The macroeconomic data series that prove statistically significant are ranked in Table 5 by the magnitude of their influence on each measure's (OTR and CM) inflation expectations. Remember that all macroeconomic data items are on the same scale (scaled by their standard deviation). Data releases whose surprise component proved statistically significant in the Gürkaynak, Sack, and Swanson (2003, Table 3) study, are noted with an asterisk. All statistically significant regression coefficients have the expected sign, except consumer credit and housing starts. ${ }^{11}$

Greater than expected numbers for consumer credit and housing starts numbers might be thought of as "bullish"; yet, the regression coefficient is negative. The six common variables whose surprise components bear most heavily on both measures of inflation expectations are the employment cost index, the Purchasing Managers' Index, CPI, retail sales, factory orders, and personal income. The capacity utilization rate was the most significant mover of inflation expectations using the CM measure, while the ECI mattered the most in the OTR measure.

We repeat the regression analysis (3) for the core measures of CPI, PPI, and retail sales. That is, we replace the respective comprehensive (total)

\footnotetext{
${ }^{10}$ The $t$-statistics and the F-statistics are based on Newey-West (1987) corrected standard errors. We applied a standard lag length of floor $\left(4(T / 100)^{2 / 9}\right)$, where floor(.) indicates rounding down to the nearest integer and $T$ is the number of observations. This lag length is also used for the Ljung-Box statistic shown in the tables.

${ }^{11}$ Note that deficits in the Treasury budget and the trade balance are recorded as negative numbers. In other words, a positive surprise component in these variables indicates a deficit that is smaller than expected in absolute value or a surplus that is greater than expected.
}

numbers in model (3) by CPI excluding food and energy, PPI excluding food and energy, and retail sales excluding automotive. These regression results, which are not shown, have less explanatory power than the regression equations with the comprehensive numbers, as judged by the $R^{2}$. Further, while CPI retains its statistical significance, retail sales do not; PPI remains statistically significant only for the OTR measure. The results for the federal funds target variable are nearly unchanged.

Poole, Rasche, and Thornton (2002) argue that monetary policy surprises as gauged by the change in federal funds futures prices are measured with error. This is because federal funds futures prices not only change in response to monetary policy actions, but also respond to other information pertinent to the future path of the federal funds rate. Because of the measurement error introduced by such ambient price changes of federal funds futures contracts, the regression coefficient of the federal funds target variable is biased toward 0 . We deal with the error-in-variables problem by employing an instrumental-variables approach. As an instrument for the federal funds target, we use an indicator that is equal to 1 if the federal funds target exceeds its median positive value, equal to -1 if it falls short of its median negative value, and 0 otherwise. ${ }^{12}$

Table 6 shows the regression results of the instrumental-variables approach applied to equation (3). We use two different definitions of the surprise component of monetary policy actions (the federal funds target variable). First, we provide results for the concept that we have used throughout the paper - the measure suggested by Gürkaynak, Sack, and Swanson (2003), which is denoted federal funds target (GSS) in the table. Second, we present results for the surprise measure devised by Poole and Rasche (2000), which is denoted federal funds target (PR) in the table. Unlike the GSS measure, which rests on the scaled price change of the current month's federal funds futures contract (unless the monetary policy surprise happens within the last seven days of the month), the PR measure always uses the price change of the next month's federal funds futures contract. One of the regression coefficients for the federal funds target (GSS) is indeed larger (in absolute value) than without the error-in-variables correction (Table 4, CM measure), while the other is smaller (Table 3, OTR measure); also, both federal funds

\footnotetext{
${ }^{12}$ For details on this error-in-variables approach, see Greene (2002).
} 


\section{Table 3}

\section{Regression Results for the 10-year OTR Measure}

\begin{tabular}{|c|c|c|}
\hline Explanatory variable & Coefficient & $t$-statistic \\
\hline Auto sales & $-3.250 \cdot 10^{-5}$ & -0.011 \\
\hline Business inventories & $2.928 \cdot 10^{-3}$ & 0.808 \\
\hline Capacity utilization & $3.395 \cdot 10^{-3}$ & 0.514 \\
\hline Civilian unemployment rate & $-2.759 \cdot 10^{-3}$ & -1.612 \\
\hline Construction spending & $-1.604 \cdot 10^{-3}$ & -0.892 \\
\hline Consumer confidence & $3.643 \cdot 10^{-3}$ & $2.237^{* *}$ \\
\hline Consumer credit & $-2.157 \cdot 10^{-3}$ & $-1.658^{*}$ \\
\hline Consumer price index (CPI-U) & $1.016 \cdot 10^{-2}$ & $2.109 * *$ \\
\hline Durable goods orders & $1.760 \cdot 10^{-3}$ & 0.800 \\
\hline Employment cost index & $1.223 \cdot 10^{-2}$ & $2.673^{* * *}$ \\
\hline Existing home sales & $-5.957 \cdot 10^{-7}$ & -0.497 \\
\hline Factory orders & $8.538 \cdot 10^{-3}$ & $3.210^{* * *}$ \\
\hline Federal funds target & $-2.194 \cdot 10^{-1}$ & $-2.424^{* *}$ \\
\hline GDP price index (advance) & $8.201 \cdot 10^{-3}$ & 1.602 \\
\hline GDP price index (final) & $3.793 \cdot 10^{-3}$ & $1.900 *$ \\
\hline GDP price index (preliminary) & $1.617 \cdot 10^{-3}$ & 0.816 \\
\hline Goods and services trade balance (surplus) & $-4.242 \cdot 10^{-3}$ & $-2.764 * * *$ \\
\hline Hourly earnings & $4.269 \cdot 10^{-3}$ & $1.773 *$ \\
\hline Housing starts & $-3.087 \cdot 10^{-3}$ & $-1.806^{*}$ \\
\hline Industrial production & $7.385 \cdot 10^{-3}$ & 1.297 \\
\hline Initial jobless claims & $-1.840 \cdot 10^{-3}$ & $-1.996^{* *}$ \\
\hline Leading indicators & $2.114 \cdot 10^{-3}$ & 0.526 \\
\hline Purchasing Managers' Index & $1.045 \cdot 10^{-2}$ & $4.757^{* * *}$ \\
\hline New home sales & $4.375 \cdot 10^{-3}$ & $2.310 * *$ \\
\hline Nonfarm payrolls & $4.099 \cdot 10^{-3}$ & $2.673 * * *$ \\
\hline Nonfarm productivity (preliminary) & $-2.588 \cdot 10^{-3}$ & -0.545 \\
\hline Nonfarm productivity (revised) & $-2.398 \cdot 10^{-3}$ & -0.334 \\
\hline Personal consumption expenditures & $-6.524 \cdot 10^{-4}$ & -0.211 \\
\hline Personal income & $5.176 \cdot 10^{-3}$ & $1.730 *$ \\
\hline Producer price index (PPI) & $-1.634 \cdot 10^{-3}$ & -0.954 \\
\hline Real GDP (advance) & $1.010 \cdot 10^{-3}$ & 0.185 \\
\hline Real GDP (preliminary) & $-2.305 \cdot 10^{-3}$ & -0.641 \\
\hline Real GDP (final) & $-7.614 \cdot 10^{-3}$ & -1.042 \\
\hline Retail sales & $1.015 \cdot 10^{-2}$ & $2.748^{* * *}$ \\
\hline Treasury budget (surplus) & $-1.121 \cdot 10^{-2}$ & $-2.117^{* *}$ \\
\hline Truck sales & $6.420 \cdot 10^{-4}$ & 0.247 \\
\hline Intercept indicator variable $(D)$ & $-1.434 \cdot 10^{-3}$ & -0.587 \\
\hline Intercept & $-6.330 \cdot 10^{-4}$ & -0.436 \\
\hline$F$-statistic (1) & $3.621^{* * *}$ & \\
\hline$F$-statistic (2) & $3.790 * * *$ & \\
\hline$R^{2}$ & 0.081 & \\
\hline$R^{2}$ adj. & 0.059 & \\
\hline Ljung-Box statistic & $18.02 * *$ & \\
\hline Rao's score test & $13.16^{* * *}$ & \\
\hline Number of nonzero observations & 1,100 & \\
\hline Number of observations & 1,555 & \\
\hline
\end{tabular}

NOTE: $* * * / * * / *$ Indicate significance at the $1 / 5 / 10$ percent levels ( $t$-tests are two-tailed). $F$-statistics and $t$-statistics are Newey and West (1987) corrected. Federal funds target is not included in the MMS survey. F-statistic (1): all MMS survey variables and federal funds target; $F$-statistic (2): all MMS survey variables. The number of nonzero observations indicates the number of trading days where Federal Reserve communication or the surprise in a monetary policy action was priced. 


\section{Table 4}

\section{Regression Results for the 10-year CM Measure}

Explanatory variable

Auto sales

Business inventories

Capacity utilization

Civilian unemployment rate

Construction spending

Consumer confidence

Consumer credit

Consumer price index (CPI-U)

Durable goods orders

Employment cost index

Existing home sales

Factory orders

Federal funds target

GDP price index (advance)

GDP price index (final)

GDP price index (preliminary)

Goods and services trade balance (surplus)

Hourly earnings

Housing starts

Industrial production

Initial jobless claims

Leading indicators

Purchasing Managers' Index

New home sales

Nonfarm payrolls

Nonfarm productivity (preliminary)

Nonfarm productivity (revised)

Personal consumption expenditures

Personal income

Producer price index (PPI)

Real GDP (advance)

Real GDP (preliminary)

Real GDP (final)

Retail sales

Treasury budget (surplus)

Truck sales

Intercept indicator variable $(D)$

Intercept

F-statistic (1)

F-statistic (2)

$R^{2}$

$R^{2}$ adj.

Ljung-Box statistic

Rao's score test

Number of nonzero observations

Number of observations
Coefficient

t-statistic

$-4.363 \cdot 10^{-4}$

$2.325 \cdot 10^{-3}$

$1.241 \cdot 10^{-2}$

$-1.669 \cdot 10^{-3}$

$-2.740 \cdot 10^{-3}$

$3.046 \cdot 10^{-3}$

$-2.680 \cdot 10^{-3}$

$7.698 \cdot 10^{-3}$

$2.075 \cdot 10^{-3}$

$9.162 \cdot 10^{-3}$

$8.273 \cdot 10^{-4}$

$6.343 \cdot 10^{-3}$

$-9.907 \cdot 10^{-2}$

$1.466 \cdot 10^{-2}$

$4.147 \cdot 10^{-3}$

$3.469 \cdot 10^{-3}$

$-2.121 \cdot 10^{-3}$

$5.752 \cdot 10^{-3}$

$-4.455 \cdot 10^{-3}$

$2.740 \cdot 10^{-3}$

$-2.160 \cdot 10^{-3}$

$7.567 \cdot 10^{-4}$

$1.086 \cdot 10^{-2}$

$2.574 \cdot 10^{-3}$

$3.921 \cdot 10^{-3}$

$-6.456 \cdot 10^{-3}$

$-1.675 \cdot 10^{-3}$

$-1.184 \cdot 10^{-5}$

$6.184 \cdot 10^{-3}$

$-1.845 \cdot 10^{-3}$

$9.222 \cdot 10^{-3}$

$-2.707 \cdot 10^{-3}$

$-4.609 \cdot 10^{-3}$

$8.745 \cdot 10^{-3}$

$-6.082 \cdot 10^{-3}$

$-4.671 \cdot 10^{-4}$

$-2.896 \cdot 10^{-4}$

$1.676 \cdot 10^{-3}$

$2.749 * * *$

$2.867^{* * *}$

0.087

0.055

$14.47^{* *}$

1.352

785

1,110

NOTE: $* * * / * * / *$ Indicate significance at the $1 / 5 / 10$ percent levels ( $t$-tests are two-tailed). $F$-statistics and $t$-statistics are Newey and West (1987) corrected. Federal funds target is not included in the MMS survey. F-statistic (1): all MMS survey variables and federal funds target; $F$-statistic (2): all MMS survey variables. The number of nonzero observations indicates the number of trading days where Federal Reserve communication or the surprise in a monetary policy action was priced. 


\section{Table 5}

\section{Ranking of Macroeconomic Data Releases by Impact on Inflation Expectations}

\begin{tabular}{|c|c|c|c|c|}
\hline Data release & OTR sign (+/-) & CM sign (+/-) & OTR rank & CM rank \\
\hline Employment cost index* & + & + & 1 & 4 \\
\hline Capacity utilization & 0 & + & $\mathrm{N} / \mathrm{A}$ & 1 \\
\hline Treasury budget (surplus) & - & 0 & 2 & $\mathrm{~N} / \mathrm{A}$ \\
\hline Purchasing Managers' Index & + & + & 3 & 2 \\
\hline Consumer price index (CPI-U) & + & + & 4 & 5 \\
\hline Retail sales* & + & + & 5 & 3 \\
\hline Factory orders & + & + & 6 & 6 \\
\hline Personal income & + & + & 7 & 7 \\
\hline New home sales* & - & 0 & 8 & N/A \\
\hline Hourly earnings & + & 0 & 9 & N/A \\
\hline Goods and services trade balance (surplus) & + & + & 10 & 8 \\
\hline Nonfarm payrolls & + & + & 11 & 11 \\
\hline GDP price index (final) & + & + & 12 & 10 \\
\hline Consumer confidence* & + & + & 13 & 13 \\
\hline Housing starts & - & - & 14 & 9 \\
\hline Consumer credit* & - & - & 15 & 14 \\
\hline Initial jobless claims & - & - & 16 & 15 \\
\hline GDP price index (preliminary) & 0 & + & $\mathrm{N} / \mathrm{A}$ & 10 \\
\hline
\end{tabular}

NOTE: Variables in Tables 3 and 4 that are significant at the 10 percent level (based on two-tailed $t$-tests) are ranked above; 0 is not significant.

*Five of the six variables that turned out statistically significant in Gürkaynak, Sack, and Swanson (2003, Table 3).

target (PR) coefficients are larger in magnitude when corrected (original estimates not shown).

Finally, we turn to the influence of Federal Reserve communication. As discussed above, the surprise component in Federal Reserve communication is next to impossible to ascertain. Yet, following Kohn and Sack (2003), we can analyze the effect of Federal Reserve communication on the (conditional) volatility of the dependent variable. Specifically, we are interested in whether Federal Reserve communication and surprises in monetary policy actions bear on inflation rate uncertainty. Intuitively, one might expect Federal Reserve communication to decrease the uncertainty surrounding the future rate of inflation as the chairman of the Federal Reserve offers guidance about the future path of monetary policy. Also, one might expect that monetary policy actions that take the market by surprise will increase uncertainty about future inflation. Note that, if Federal Reserve communication and surprises in monetary policy actions bear on inflation uncertainty, then the error term of the regression equation (3) is heteroskedastic. Rao's score test on heteroskedasticity shows that the null hypothesis of no heteroskedasticity is indeed rejected for the OTR measure of inflation compensation (Table 3) but not for the CM inflation compensation measure (Table 4). ${ }^{13}$

To address the issue of inflation uncertainty, we use the squared residuals from regression equation (3)-the regression results of which are shown in Tables 3 and 4-in an estimation approach suggested by Amemiya $(1977,1978)$. We regress these squared residuals on the federal funds target variable, an indicator variable that is equal to 1 on days where Federal Reserve communication was priced in the market (and 0 otherwise), and the previously introduced intercept indicator variable $(D)$. The regression

\footnotetext{
${ }^{13}$ For Rao's score test, see Amemiya (1985).
} 


\section{Table 6}

Instrumental-Variables Approach

Panel A: OTR measure

\begin{tabular}{llc}
\hline Explanatory variable & Coefficient & $t$-statistic \\
\hline Federal funds target (GSS) & $-2.016 \cdot 10^{-1}$ & $-2.710^{* *}$ \\
Federal funds target (PR) & $-2.659 \cdot 10^{-1}$ & $-3.191^{* * *}$
\end{tabular}

Panel B: CM measure

\begin{tabular}{llc}
\hline Explanatory Variable & Coefficient & $t$-statistic \\
\hline Federal funds target (GSS) & $-1.671 \cdot 10^{-1}$ & $-2.975^{* * *}$ \\
Federal funds target (PR) & $-1.239 \cdot 10^{-1}$ & $-2.575^{* *}$
\end{tabular}

NOTE: ${ }^{* * *} / * *$ Indicate significance at the $1 / 5$ percent levels ( $t$-tests are two-tailed; $t$-statistics are Newey and West (1987) corrected). GSS and PR indicate the federal funds market measure for monetary policy surprises as suggested by Gürkaynak, Sack, and Swanson (2002) and Poole and Rasche (2000), respectively.

\section{Table 7}

\section{Inflation Uncertainty}

Panel A: OTR measure

\begin{tabular}{lcc}
\hline Explanatory variable & Coefficient & $t$-statistic \\
\hline Federal Reserve communication & $-8.632 \cdot 10^{-3}$ & $-3.989^{* * *}$ \\
Federal funds target & $1.547 \cdot 10^{-3}$ & $4.009^{* * *}$ \\
Intercept indicator variable $(D)$ & $9.189 \cdot 10^{-4}$ & $4.017^{* * *}$ \\
Intercept & $1.049 \cdot 10^{-3}$ & $4.157^{* * *}$ \\
Number of nonzero observations & 166 & 1,555
\end{tabular}

Panel B: CM measure

\begin{tabular}{lcc}
\hline Explanatory variable & Coefficient & $t$-statistic \\
\hline Federal Reserve communication & $3.021 \cdot 10^{-3}$ & 1.295 \\
Federal funds target & $5.160 \cdot 10^{-4}$ & 1.107 \\
Intercept indicator variable $(D)$ & $4.173 \cdot 10^{-4}$ & 1.104 \\
Intercept & $1.381 \cdot 10^{-3}$ & $3.740^{* * *}$ \\
Number of nonzero observations & 117 & \\
Number of observations & 1,110 \\
& \\
NOTE: ${ }^{* * *}$ Indicates significance at the 1 percent level (t-tests are two-tailed). The variable Federal Reserve communication equals 1 \\
on trading days on which Chairman Greenspan's semi-annual testimony to Congress (formerly known as Humphrey-Hawkins testimony) \\
or speeches and other testimonies of Chairman Greenspan were priced in the market. The number of nonzero observations indicates \\
the number of trading days where Federal Reserve communication or the surprise in a monetary policy action was priced.
\end{tabular}


results, which are presented in Table 7 , indicate that neither Federal Reserve communication nor monetary policy surprises bear on the conditional variance of the CM measure of inflation compensation. This finding is not surprising, given that Rao's score test does not suggest heteroskedasticity. Things are different with the OTR measure of inflation compensation. Here, Rao's score test indicates heteroskedasticity, and, indeed, the coefficients for the variables Federal Reserve communication and federal fund target are statistically significant and have the expected sign. Hence, we conclude that, at least judged by one of our two measures of inflation compensation, Federal Reserve communication diminishes the uncertainty surrounding the future rate of inflation, while surprises in monetary policy actions increase it.

\section{CONCLUSION}

Do monetary policy actions that are tighter or easier than expected by the federal funds futures market bear on the average rate of inflation that economic agents expect to prevail over the next 10 years? Moreover, do surprises in macroeconomic data releases lead economic agents to update their beliefs about the average rate of inflation they expect for the next 10 years; if so, which data series matter the most? We gauged inflation expectations by two different measures of inflation compensation, both of which are derived from the market valuation of the expected cash flows of nominal and inflationindexed Treasury securities.

We find that surprises in monetary policy actions bear on both measures of inflation expectations. Monetary policy actions that are viewed as tighter (easier) than expected by the market lead economic agents to revise down (up) their expected rate of inflation. Further, one measure indicates that Federal Reserve communication reduces uncertainty about the future rate of inflation, while surprises in monetary policy actions increase uncertainty about the path the rate of inflation is going to take. We also show that surprises in macroeconomic data releases matter. In particular, we show that the surprise components in data releases for the employment cost index, the Purchasing Managers' Index, CPI, retail sales, factory orders, and personal income bear most heavily on both measures of inflation expectations.

\section{REFERENCES}

Amemiya, Takeshi. "A Note on a Heteroscedastic Model." Journal of Econometrics, November 1977, 6(3), pp. 365-70.
Amemiya, Takeshi. "Corrigenda.” Journal of Econometrics, October $1978,8(2)$, p. 275.

Amemiya, Takeshi. Advanced Econometrics. Cambridge, MA: Harvard University Press, 1985.

Balduzzi, Pierluigi; Elton, Edwin J. and Green, Clifton T. "Economic News and Bond Prices: Evidence from the U.S. Treasury Market." Journal of Financial and Quantitative Analysis, December 2001, 36(4), pp. 523-43.

Bernanke, Ben S. "An Unwelcome Fall in Inflation?" Remarks before the Economics Roundtable, University of CaliforniaSan Diego, La Jolla, California, July 23, 2003. www.federalreserve.gov/boarddocs/speeches/2003/ 20030723/default.htm.

Emmons, William R. "The Information Content of Treasury Inflation-Indexed Securities.” Federal Reserve Bank of St. Louis Review, November/December 2000, 82(6), pp. 25-37.

Fleming, Michael J. and Remolona, Eli M. "What Moves Bond Prices?" Journal of Portfolio Management, Summer 1999, 25(4), pp. 28-38.

Fleming, Michael J. and Remolona, Eli M. "What Moves the Bond Market?" Federal Reserve Bank of New York Economic Policy Review, December 1997, 3(4), pp. 31-50.

Greene, William H. Econometric Analysis. 5th edition. Upper Saddle River, NJ: Prentice-Hall, August 2002.

Gürkaynak, Refet S.; Sack, Brian P. and Swanson, Eric T. "The Excess Sensitivity of Long-Term Interest Rates: Evidence and Implications for Macroeconomic Models." Working paper, Division of Monetary Affairs, Board of Governors of the Federal Reserve System, April 4, 2003. www.clevelandfed.org/CentralBankInstitute/conf2003/ august/sensitivity_apr4.pdf.

Gürkaynak, Refet S.; Sack, Brian P. and Swanson, Eric T. "Market-Based Measures of Monetary Policy Expectations." Working paper, Division of Monetary Affairs, Board of Governors of the Federal Reserve System, August 1, 2002. www.federalreserve.gov/pubs/feds/2002/200240/ 200240 pap.pdf.

Kohn, Donald L. and Sack, Brian P. "Central Bank Talk: Does It Matter and Why?" Paper presented at the Macroeconomics, Monetary Policy, and Financial Stability Conference in honor of Charles Freedman, Bank of Canada, Ottawa, Canada, June 20, 2003. 
www.federalreserve.gov/boarddocs/speeches/2003/ 20030620/paper.pdf.

Kuttner, Kenneth N. "Monetary Policy Surprises and Interest Rates: Evidence from the Fed Funds Futures Market." Journal of Monetary Economics, June 2001, 47(3), pp. 523-44.

Newey, Whitney K. and West, Kenneth D. "A Simple, Positive Semi-Definite, Heteroskedasticity and Autocorrelation Consistent Covariance Matrix." Econometrica, May 1987, pp. 703-08.

Poole, William and Rasche, Robert H. "Perfecting the Market's Knowledge of Monetary Policy.” Journal of Financial Services Research, December 2000, 18(2-3), pp. 255-98.

Poole, William; Rasche, Robert H. and Thornton, Daniel L. "Market Anticipations of Monetary Policy Actions." Federal Reserve Bank of St. Louis Review, July/August 2002, 84(4), pp. 65-93.

Sack, Brian P. "Deriving Inflation Expectations from Nominal and Inflation-Indexed Treasury Yields." Journal of Fixed Income, September 2000, 10(2), pp. 6-17.

Stock, James H. and Watson, Mark W. "Forecasting Inflation." Journal of Monetary Economics, October 1999, 44(2), pp. 293-335.

Watson, Mark W. Commentary. Federal Reserve Bank of St. Louis Review, July/August 2002, 84(4), pp. 95-97. 
RE V I E W 